\title{
Evaluation of Air Pollution Tolerance Index (APTI) Of Some Selected Ornamental Shrubs in Enugu City, Nigeria.
}

\author{
${ }^{1}$ Enete, Ifeanyi. C, ${ }^{2}$ Ogbonna, C.E \\ ${ }^{I}$ Dept. of Geography \& Meteorology, Nnamdi Azikiwe University, Awka \\ ${ }^{2}$ Dept. of Environmental Management, Abia State University, Uturu
}

\begin{abstract}
Enugu Urban is currently the capital of Enugu state and the largest city in the eastern part of Nigeria.. In the last few years, traffic population and industrial activities has grown at a geometric proportion, with the attendant consequences of increased air pollution. Five species of streetscape plants were identified as ornamental shrubs. The Vegetation monitoring in terms of its APTI was evaluated. The APTI was formulated by four plant physiology indicators namely leaf extract $\mathrm{pH}$, Relative water content, Ascorbic acid and chlorophyll content. The APTI values ranged between 10.60 and 14.32 on yellows Bush and Ixora Red respectively. The Ornamental shrubs with lower APTI values (sensitive) were recommended to be utilized as bioindictors of poor urban air quality while shrubs with high APTI values (Tolerant) are to be planted around areas anticipated having high air pollution load.
\end{abstract}

Keywords: Ornamental, Shrubs, APTI, Bioindicators, streetscape, plants.

\section{Introduction}

In Enugu Urban, there has been a significant development activity in the automobile sector, in terms of sharp increase in vehicular population. It has contributed on the city's carrying capacity of air pollutants like $\mathrm{NO}_{x}, \mathrm{SO} 2, \mathrm{CO}, \mathrm{CO}_{2}$, particles and lead. The impact of such anthropogenic activity is responsible for variety of diseases on both human and plant communities. Shrubs play important roles in monitoring and maintaining the ecological balance by actively participating in the cycling of nutrients and gases like carbon dioxide, Oxygen and also provide enormous leaf area for impingement, absorption and accumulation of pollutants to reduce the pollution level in the air environment (Escobedo et al., 2008). Several contributors agree that air pollution affects both plant and shrub growth adversely (Rao, 2006; Bhatia, 2006). There are various ways and means to mitigate the urban environmental pollution. Planting of trees and shrubs for abatement of pollution and improvement of environment is an effective way and well recognized throughout the world (Nugrahani et al., 2012).

Since plant organs are exposed to the atmosphere and the leaves continuously exchange gases, a pollutant is reflected on the plant health. These plants can be effectively used as bioindicators of urban air quality as well as a beautification agent (Mondal et al., 2011). Mitigating this pollution is a high priority for both human health and amelioration of environmental conditions in the city. As such, one possible approach is to plant appropriate plants and shrubs at strategic locations such as in towns and along the road sides. Plant selection criteria should not only be limited to colorful flower and leaves, robustness, watering issues and space but it should also be able to help improve air quality (Nugrahari et al.,) 2012). Plants and Shrubs when exposed to airborne pollutants, experience physiological and biochemical changes before exhibiting visible damage to leaves (Dohman et al.,1990). The response of plants to air pollution at physiological and biochemical levels can be understood by analyzing the factors that determines resistance and susceptibility.

It is possible to estimate the overall effect of a large number of pollutants as total pollution by measuring changes in the plant (Agboire, 2009). Singh and Verma (2007) by using the data obtained from detailed biochemical estimations of vegetation samples (including chlorophyll, ascorbic acid content, and $\mathrm{pH}$ and relative water content) calculated the air pollution tolerance index (APTI). There are many factors controlling tolerance in plants. For example, the importance of $\mathrm{pH}$ in modifying the toxicity of $\mathrm{SO}_{2}$ has been shown. Singh and Verma (2007) reported that plants with lower $\mathrm{pH}$ are more susceptible, while those with $\mathrm{pH}$ around 7 are more tolerant.

Ascorbic acid content is another parameter that may be used to decide the tolerance of plant to air pollution. It plays a significant role in light reaction of photosynthesis (Singh and Verma, 2007), activates defense mechanism (Arora et al., 2002), and under stress condition, it can replace water from light reaction (Singh and Verma, 2007). Joshi and Swami (2007) also reported that ascorbic acid is a natural antioxidant in plants that play an important role in pollution tolerance. It is also a factor in cell wall synthesis, defense and cell division. It is also a strong reducer and plays important roles in photosynthetic carbon fixation, with the reducing power directly proportional to its concentration. So it has been given top priority and used as a multiplication factor in the formula. High $\mathrm{pH}$ may increase the efficiency of conversion from hexose sugar to 
AA, while Low leaf extract $\mathrm{pH}$ has also showed good correlation with sensitivity to air pollution (Escobedo et al., 2008; Pasqualini et al., 2001; Conklin, 2001; Lui and Ding; 2008).

Total chlorophyll (TCh) is another parameter in APTI that is so important. Depletion in Chlorophyll immediately causes a decrease in productivity of plant and subsequently plant exhibits poor vigor. Photosynthetic efficiency was noted to be strongly dependent on leaf pH is low (Singh and Verma, 2007).Water is a necessity for plant life. Shortage of water may cause severe stress to terrestrial plants (Singh and Verma, 2007); High water content within the plants body will help to maintain its physiological balance under stress conditions such as exposure to air pollution when the transpiration rates are usually high.

Vegetation and shrubs in Enugu City has been exposed to a variety of pollutants. The ability of plants species to remove pollutants has been evaluated (Liu et al., 2007). The objective of this study is to evaluate air pollution tolerance of some selected ornamental shrubs species currently growing along central business district (CBD) of Enugu Urban city of Nigeria.

\subsection{Sampling Procedure}

\section{Material and Methods}

Plants were randomly selected from one of the major roads within the central business district of Enugu Urban area - Agbani Road. The choice of this route was based on its high traffic population. Six replicates of fully matured leaves were taken and immediately taken to the laboratory in a heatproof container at Zik Avenue, for analysis. The leaf fresh weight was taken immediately upon getting to the laboratory.

\subsection{Air pollution Tolerance Index Technique.}

To obtain the four parameters in APTI formula, Samples were treated as follows:

\subsubsection{Relative Leaf Water Content (RWC)}

The method described by Singh (1977) and Agbaire and Esiefarenrhe (2009) was applied to determine and calculate relative leaf water content as follows:

$$
\begin{aligned}
\text { RWC } & =\frac{\mathrm{FW}-\mathrm{DW}}{\mathrm{TW}-\mathrm{DW}} \times 100 \\
\mathrm{FW} & =\text { Fresh weight } \\
\mathrm{DW} & =\text { Dry weight } \\
\mathrm{TW} & =\text { Turgid weight }
\end{aligned}
$$

Fresh weight was obtained by weighing the fresh leaves. The leaves were then immersed in water over night at $70^{\circ} \mathrm{C}$ and reweighed to obtain the dry weight.

\subsubsection{Total Chlorophyll Content (TCh)}

Following the method described by Department of biology, East China Normal University (1980), TCh analysis was obtained as follows: $0.5 \mathrm{~g}$ fresh leaves material was grounded and diluted to $10 \mathrm{ml}$ in distilled water. A subsample of $2.5 \mathrm{ml}$ was mixed with $10 \mathrm{ml}$ acetone and filtered. Optical density was read at $645 \mathrm{~nm}$ (D645) and 663nm (D663). Optical density of TCh $\left(\mathrm{C}_{\mathrm{T}}\right)$ is the sum of chlorophyll a (D645) density and chlorophyll a (D663) density as follows:

$$
\begin{array}{ll}
\mathrm{C}_{\mathrm{T}} & =20.2(\mathrm{D} 645)+8.02(\mathrm{D} 663) \\
\mathrm{TCh} & =(\mathrm{mg} / \mathrm{g} \mathrm{DW}) \text { was calculated as follows } \\
\mathrm{TCh} & =0.1 \mathrm{C}_{\mathrm{T}} \times(\text { leaf DW/leaf FW })
\end{array}
$$

\subsubsection{Ascorbic Acid (AA) Content Analysis}

Ascorbic acid content (expressed in $\mathrm{Mg} / \mathrm{g}$ ) was measured using spectrophotometric method (Bajaj and Kaur, 1981). $1 \mathrm{~g}$ of the fresh foliage was put in a text-tube, $4 \mathrm{ml}$ oxalic acid EDTA extracting solution was added, them $1 \mathrm{ml}$ of Orthophospheric acid and then $1 \mathrm{ml} 5 \%$ tetraoxosulphate (vi) acid added to this mixture, 2 $\mathrm{ml}$ of ammonium molybdate was added and then $3 \mathrm{ml}$ of water. The solution was then allowed to stand for 15 minutes after which the absorbance at $760 \mathrm{~nm}$ was measured with a spectrophotometer. The concentrations of ascorbic acid in the sample were then extrapolated from a standard ascorbic.

\subsubsection{Leaf Extract pH}

This was done following the method adapted by Agbarie and Esiefarenrhe (2009). 5g of the fresh leaves was homogenized in $10 \mathrm{ml}$ demonized water. This was filtered and the $\mathrm{pH}$ of the leaf extract determined after calibrating $\mathrm{pH}$ water with buffer solution of $\mathrm{pH} 4$ and 9

\subsubsection{Air Pollution Tolerance Index (APTI) Determination}

This was done following the method of Singh and Rao (1983). The formula of APTI is given as:

$$
\text { APTI } \quad=\frac{\mathrm{A}(\mathrm{T}+\mathrm{P})+\mathrm{R}}{10}
$$




\begin{tabular}{ll}
\hline $\mathrm{A}$ & $=$ Ascorbic acid content $(\mathrm{mg} / \mathrm{g})$ \\
$\mathrm{T}$ & $=$ Total Chlorophyll $(\mathrm{mg} / \mathrm{g})$ \\
$\mathrm{P}$ & $=\mathrm{pH}$ of leaf extract \\
$\mathrm{R}$ & $=$ Relative water content of leaf $(\%)$
\end{tabular}

\section{Results}

Ornamental shrubs growing in polluted environment often respond and show significant changes in their morphology, physiology and biochemistry. Lakshmi et al., (2008) reported that plants that are constantly exposed to environmental pollutants absorb, accumulate and integrate these pollutants into their systems. The analysis values of the four biochemical parameters along with the calculated air pollution tolerance indices for the five ornamental species are shown in table 1.

Table 1. Air Pollution Tolerance Index of selected Ornamental species.

\begin{tabular}{|l|l|l|l|l|l|}
\hline Ornamental & $\begin{array}{l}\text { Ascorbic } \\
\text { acid }\end{array}$ & $\begin{array}{l}\text { Relative water } \\
\text { content }(\boldsymbol{\%})\end{array}$ & $\mathbf{p H}$ & $\begin{array}{l}\text { Total Chlorophyll } \\
(\mathbf{m g} / \mathbf{g})\end{array}$ & APTI \\
\hline Ixora Red & 2.95 & 89.36 & 5.30 & 12.96 & 14.32 \\
\hline Yellow Bush & 2.00 & 75.0 & 6.40 & 9.10 & 10.60 \\
\hline Masquerade Pine & 2.97 & 61.70 & 6.00 & 11.12 & 12.26 \\
\hline Tuja Pine & 2.600 & 68.87 & 5.50 & 10.31 & 11.00 \\
\hline Yellow ficus & 1.99 & 87.50 & 6.30 & 13.17 & 12.63 \\
\hline
\end{tabular}

From table 1, result indicates that ornamental shrubs had varied degree of tolerance index to air pollution. The air pollution tolerance index ranged from 10.60 to 14.32 with Ixora Red having the highest APTI value and Yellow Bush with lowest APTI value. Based on the previous studies (Lakshni et al, 2008; Agbarie and Esiefarienrhe, 2009) sensitive ones can be utilized as bioindicators of the air quality, while those species in the tolerant group can be used for development of streetscape greening.

\section{Discussion}

Sensitivity of plants are expressed by low APTI values. Singh et al., (1991) suggested a method of determining Air Pollution Tolerance Index APTI) by synthesizing the values of form different bio-chemical parameters leaf extract $\mathrm{pH}$, ascorbic acid, total chlorophyll and relative water contents. According to Yan-Ju and Hui(2008), air pollution tolerance index of most shrubs were high than those of trees, suggesting that shrubs, in general, were more tolerant to air pollution than trees. An overview of the result obtained from this current study reveals that different plants respond differently to air pollutants (table1). The variation of the APTI can be attributed to the variation in any of the four physiological factors which governs the computation of the index. In the current study, the orders of tolerance of Oriental shrubs are in this order: Ixora Red, Yellow Ficus, Masquerade Pine, Tuja Pine, and Yellow bush. The implication is that Ixora Red should be preferred where pollution appears high because of its ability to tolerate more pollutants. Ornamental shrubs like Yellow Bush showed are used as indicators of poor air quality.

\section{Conclusion}

Air pollution tolerance index determinations are of importance because with increased urbanization, industrialization and geometric increase in traffic population in Enugu City, there are bound to be more air pollution. The result of the current study becomes handy for future planning. The Study also provides useful information for selecting tolerance species for streetscaping and microclimate modification. Species that are tolerant should be considered in advance for use, especially where air pollutants are high conversely, species that are sensitive should be utilized as bioindicators of urban air quality.

\section{Reference}

[1] Agbaire, P.O (2009). Air pollution Tolerance Indices of Some Plants around Erhoike-kokori oil exploration site of Delta state, Nigeria. International Journal of PhysicalSsciences, 4:366-368.

[2] Agbaire,P.O and Esiefarienrhe,E(2009). Air Pollution Tolerance Indices of Some Plants around Otorogun Gas Plants in Delta State, Nigeria. Journal of Applied Sciences and Environmental Management, 13:11-14.

[3] Arora, A. Sairam, R.K and Srivaastava,G.C (2002). Oxidative Stress and Antioxidative System in Plants. Current Science,82:1227 -1238 .

[4] Bajaj, K.L and Kaur, G (1981). Spectrophotometric Determination of Ascorbic Acid in Vegetables and Fruits. Analyst, 106:117120.

[5] Bhatia, S.C (2006). Environmental Chemistry. CBS Publishers and Distributors, India

[6] Conklin, P (2001). Recent Advances in the Role and Biosynthesis of Ascorbic Acid in Plants. Plant Cell Environment, 24:383 394.

[7] Department of Biology, East China Normal University (1980). Experiment Instruction of Plant physiology. Peoples Education Press. 
[8] Dohman, G.P. Loppers, A. Langebartels, C (1990). Biochemical Response of Norway spruce (Picea Abies (L) karst) toward 14Month Exposure to Ozone and Acid Mist, Effect on Amino acid,Glutathione and Polyamine Titers. Environmental Pollution, 64: $375-383$

[9] Escobedo, F.J. Wagne, J.E. Nowak, D.J. DeleMaza, C.L. Rodriguez, M. and Crane, D.E (2008). Analyzing the Cost Effectiveness of Santiago, Chiles Policy of using Urban Forests to Improve Air quality. Journal of Environmental Management, 86:148-157.

[10] Joshi, P.C and Swami, A (2007). Physiological Responses of Some Tree Species under Roadside Automobile Pollution Stress around City of Haridwar, India.

[11] Lakshmi, P.S. Sravanti, K..L and Srinivas, N.(2008). Air Pollution Tolerance Index of Various Plant Species Growing in Industrial Areas. The Ecoscan, 2(2): 203-206.

[12] Liu, Y.J and Ding, H (2008). Variation in Air Pollution Tolerance Index of Plants near a Steel Factory: Implication for Landscape - Plant Species Selection for Industrial Areas. Wseas Trans. Environmental Development, 4:24-32.

[13] Liu, Y.J. Mu, Y.J and Zhu, Y. G (2007). Which Ornamental Plant Species Effectively Remove Benezene from Indoor Air? Atmosphere Environment, 51:650-654

[14] Mondal, D. Gupta, S and Datta, J. K (2011). Anticipated Performance Index of Some Tree Species Considered for Green Belt Development in an Urban Area. Plant Science, 2(4):99-106.

[15] Nugrahani, P. Prasetyawati, E.T, Sugijanto, O and Pumobasuki, H (2012). Asian Journal of Biological Sciences, 3(2):298-302.

[16] Pasqualini, S. Batini, P. Ederli, L (2001). Effects of Short- term Ozone Fumigation on Tobacco Plants: Response of the Scavenging System and Expression of the Glutathione Reductase, Plant Cell Environment, 24:245-252.

[17] Rao, C.S (2006). Environmental Pollution Control Engineering. New Age International Publishers, Revised Second Edition.

[18] Singh, A (1977): Practical Plant physiology. Kalyari Publishers. New Delhi.

[19] Singh, S.K and Rao, D.N (1983). Evaluation of plants for their Tolerance to Air Pollution ,Proceedings of the symposium on Air Pollution Control, pp.218-224.

[20] Singh, S.K. Rao, D. N. Agrawal, M. Pandey, J. and Narayan, D(1991). Air Pollution Tolerance Index of Plants. Journal of Environmental Management, 32:45-55

[21] Singh, S.N and Verma, A (2007). Phytoremediation of Air Pollutants: A Review. In: Environmental Bioremediation Technology, Singh, S.N and Tripathi, R. D (eds). Springer, Berlin Heidelberg, pp.293-314.

[22] Yan-Ju, L. and Hui, D (2008). Variation in Air Pollution Tolerance Index of Plants near Steel Factory. Implication for landscapePlant Species Selection for Industrial Areas. Environmental development, 1(4):24-30. 